\title{
Loan Market Competition and Bank Risk-Taking
}

\author{
Wolf Wagner
}

Received: 9 October 2008 / Revised: 3 August 2009 / Accepted: 7 August 2009 /

Published online: 3 September 2009

(C) The Author(s) 2009. This article is published with open access at Springerlink.com

\begin{abstract}
Recent literature (Boyd and De Nicoló, J Finance 60:1329-1343, 2005) has argued that competition in the loan market lowers bank risk by reducing the risk-taking incentives of borrowers. Using a model where competition arises from falling switching costs for entrepreneurs, we show that the impact of loan market competition on banks is reversed if banks can adjust their loan portfolios. The reason is that when borrowers become safer, banks want to offset the effect on their balance sheet and switch to higher-risk lending. They even overcompensate the effect of safer borrowers because loan market competition erodes their franchise values and thus increases their risk-taking incentives.
\end{abstract}

Keywords Loan market competition · Risk shifting • Bank stability

JEL Classification $\mathrm{G} 21 \cdot \mathrm{L} 11$

\section{Introduction}

Competition in the banking sector is typically seen as detrimental to financial stability. The basic idea is that when banks compete intensely for deposits, interest

\footnotetext{
W. Wagner $(\bowtie)$

CentER, Tilburg University, Tilburg, The Netherlands

e-mail: wagner@uvt.nl

W. Wagner

European Banking Center, Tilburg University, Tilburg, The Netherlands

W. Wagner

TILEC, Tilburg University, Tilburg, The Netherlands

W. Wagner

Department of Economics, Tilburg University, Postbus 90153,

5000 LE Tilburg, The Netherlands
} 
rates fall and their franchise value is eroded. Banks have then less to lose from a default and their incentives to take on risk increase. ${ }^{1}$ This argument has been very important in shaping banking regulation around the world, for instance in the form of competition and merger policies.

A recent influential paper by Boyd and De Nicoló (2005) has challenged this view. Boyd and De Nicoló (BdN, henceforth) start from the simple observation that when banks compete more in the deposit market, they are also likely to compete more in the loan market. Loan rates should hence decline. BdN show that this gives rise to a new channel which operates through the asset side of banks' balance sheets. First, lower loan rates raise profits for borrowers and thus make bankruptcy less likely. Moreover, for the same reason that banks choose higher risk when deposit rates increase, borrowers choose to be safer when loan rates decrease. Both effects reduce the riskiness of bank loans and thus counter the traditional channel. BdN consequently argue that the lending market should be central to future models of bank stability.

This paper extends the analysis of the lending channel. In $\mathrm{BdN}$ borrowers are implicitly assumed, through their influence on the risk of firms, to have complete control over the riskiness of banks. We argue that, while borrowers may determine the riskiness of their firms, it is banks who decide how much risk they ultimately want to take on. They do this, for example, by deciding how much to lend in total or whether or not to lend to risky industries. Banks also determine the risk of their loan portfolio through their lending standards, screening and monitoring efforts and through covenants. To allow for this, we introduce in a model with a lending channel as in $\mathrm{BdN}$ the possibility for banks to select among different types of borrowers. Thus, we essentially allow for both a risk choice of borrowers as in $\mathrm{BdN}$ and a risk choice for banks. We find that this alteration reverses the stability effect of the lending channel.

We consider a model where a bank finances a single entrepreneur and sets a lending rate. The entrepreneur can set the risk of his project, and his incentives to do so depend on the lending rate as in BdN. There are different types of entrepreneurs in the economy, and the bank can decide which one to finance. The entrepreneurs differ according to the risk-return profile of their projects such that for a given lending rate their risk choice results in a different project risk. The bank faces competition from an entrant at an intermediate stage, which restricts the lending rate it can charge.

In this model, the result of $\mathrm{BdN}$ obtains for a given entrepreneur type the bank finances. We model competition as a reduction in the switching costs an entrepreneur faces at the intermediate stage. This reduction lowers the lending rate the bank can charge to an entrepreneur without losing the entrepreneur to the entrant. The lower lending rate, in turn, reduces the entrepreneur's incentives to take on risk, and the bank ends up safer as a consequence.

This result, however, no longer holds when the bank can choose among the different entrepreneurs. In its decision of which entrepreneur to finance, the bank fully anticipates the risk level that results from an entrepreneur's choice at a given lending rate. When, due to more intense competition, the maximum lending rate it can charge to all entrepreneurs in the economy declines, the bank hence anticipates that every given entrepreneur will reduce the riskiness of his project. To understand

\footnotetext{
${ }^{1}$ See, among others, Keeley (1990), Allen and Gale (2000), Hellman et al. (2000) and Repullo (2004).
} 
how the bank will react to this, one has to recall the usual trade-off a bank faces when it finances a riskier project. On one hand, more risk imply higher returns when the project succeeds. On the other hand, there is a higher chance that the entrepreneur defaults, in which case the bank loses the agreed repayment. The result of this tradeoff is a desired level of project risk a bank wants to take on, which depends on the lending rate the bank can charge. If the bank continues to finance the entrepreneur it found optimal to finance before the increase in competition, the resulting project risk would fall below the desired level. The bank has hence an incentive to change to an entrepreneur with a project of a higher risk-profile who now chooses the same level of project risk as the bank's old entrepreneur.

This is, however, not the only effect of competition since at the same time the bank's desired risk-taking increases. The reason is that when lending rates decline, the bank has less to lose from a failure of an entrepreneur's project (this effect is basically the same as the one of deposit market competition increasing bank risktaking). As a result, the bank finds it optimal to finance an entrepreneur that chooses a project risk that is even higher than the one of the bank's old entrepreneur. Banking stability, therefore, unambiguously falls.

Recent literature has extended the lending channel in different directions. Martínez and Repullo (2006) show that competition in the loan market may undermine bank stability by reducing banks' margins. They demonstrate that this can give rise to a U-shaped relation between competition and stability. Boyd et al. (2006) derive empirical predictions from a model where banks, besides in loans, also invest in safe assets and find support for their theory. Hakenes and Schnabel (2007) show that competition in the lending market may induce banks to alter the correlation of the loans in their portfolio, with the effect on stability potentially going either way. ${ }^{2}$

In our model banks modify their risk by channeling lending to borrowers with riskier project types (for example, by increasing lending in high-risk industries). This is one dimension along which banks can react to safer borrowers following a fall in lending rates. There are several other margins through which banks can alter their risk, such as by lowering their screening and monitoring efforts, reducing collateral requirements and loan restrictions, or by leveraging up their capital structure. While our paper suggests a relation between these margins and competition due to bank risk-taking incentives, recent literature has emphasized other factors. In Dell'Ariccia and Marquez (2004), faced with more intense competition, banks switch to more opaque borrowers as this increases adverse selection problems for competitors. In a similar vein, Boot and Thakor (2000) argue that competition among banks increases their incentives to make relationship loans, as opposed to transactional loans. The presence of these channels suggest that the impact of competition on bank stability described in the present paper may be dampened because banks can insulate themselves from higher lending market competition by investing in loans with higher informational rents, translating into higher switching costs in our setting. Hauswald and Marquez (2006) show that higher competition can reduce banks' incentives to

\footnotetext{
${ }^{2}$ Studying the impact of bank heterogeneity, De Nicoló and Loukoianova (2007) allow banks, as in our model, to choose between different types of entrepreneurs. However, they employ a parameterization where entrepreneurial risk choices do not depend on their type in equilibrium (the reason is a precisely offsetting effect that comes from a change in the demand for loans) and hence a bank's risk does not change when it switches type.
} 
acquire information about borrowers. They also show that information acquisition can act as a deterrent to competition, by creating an adverse selection problem for competitors. This may amplify the effect of competition, as lower information acquisition in turn makes banks compete more aggressively. This channel is also expected to increase the impact of competition in our setting as it results in banks effectively lowering switching costs in response to competition. Finally, while in our paper a link between competition and bank risk arises from risk-shifting motives due to limited liability (both on the bank's and the entrepreneur's side), Dell'Ariccia and Marquez (2006) present a model where competition affects bank risk through banks' incentives to screen. In their setting, a higher inflow of unknown borrowers into the pool of borrowers reduces adverse selection problems among banks. This can make it optimal for banks to lower their amount of screening. Even though this may be desirable from a welfare perspective, Dell'Ariccia and Marquez show that the resulting increase in lending activity exposes banks to greater risks and hence reduces financial stability.

The paper proceeds as follows. The next section sets up the model and analyzes the impact of competition on bank risk-taking. The final section concludes.

\section{The model}

We consider a setting where a bank finances an entrepreneur through a loan. There is the classical bank risk-shifting problem emphasized in the literature, which arises because banks' financing costs are risk-insensitive. As in $\mathrm{BdN}$, there is also a riskshifting incentive at the level of the entrepreneur since in the case of default he is protected by limited liability. This risk-shifting problem is lessened when lending rates decline since the entrepreneur then participates to a larger extent in the success of his project.

Our model closely resembles the one of $\mathrm{BdN}$ but there are the following differences. First, we introduce the possibility for banks to choose between different types of entrepreneurs (but entrepreneurs still determine the risk level of their projects, as in $\mathrm{BdN}$ ). These entrepreneurs differ in their risk choice, that is, at the same lending rate they would choose different levels of risks. One can think of this heterogeneity in risk choices as the result of entrepreneurs having projects that differ with respect to their risk-return trade-off, or as entrepreneurs having different preferences for risk.

Moreover, we shut down the traditional channel by assuming that interest rates in the deposit market are given. We can thus isolate the effect of competition in the lending market (we demonstrate later that incorporating the traditional channel only strengthens our results). It also serves to simplify the analysis by allowing us to keep the number of projects financed by a bank constant.

Finally, we model competition differently. In BdN increased competition is due to an increase in the number of banks that compete in a Cournot fashion. Since we have a continuum of entrepreneur types here (rather than a single type as in $\mathrm{BdN}$ ), this setup would create technical complications because banks would then play Cournot in a large number of (interacting) markets. Instead, we model more intense competition through declining switching costs for entrepreneurs when they want to move to another bank. 


\subsection{The setup}

There are two dates ( 0 and 1$)$ and three classes of agents: depositors, entrepreneurs and banks. All agents are risk neutral. Besides investing in the bank, depositors also have the possibility to invest in a storage technology which gives a return of $r^{S}$ for every unit invested at date 0 . There is a deposit insurance system in place which fully insures depositors. Depositors are hence risk-insensitive. The deposit insurance system charges a flat premium of $\pi$ per unit of deposits. A bank can thus raise funds at a constant rate of $r^{D}:=r^{S}+\pi$.

There is a continuum of entrepreneurs indexed by $k$ (with $k \in\left[k_{\min }, k_{\max }\right]$ ) which differ with respect to their projects: an entrepreneur $k$ 's project pays in the case of success $s-k$. In the case of failure all projects pay zero. The probability of success is given by $p(s)$ with $p_{s}<0$ (subindices will denote partial derivatives). Entrepreneurs can choose $s(s \in[0, \bar{s}])$, that is the risk of the project. The risk choice is not observable but entrepreneurial types are. The following conditions on $p(s)$ ensure concavity of the entrepreneur's problem: $p(0)=1, p(\bar{s})=0$ and $p_{s}<0, p_{s, s}<0$. A project requires one unit of funds. Entrepreneurs have no funds of their own and have to borrow from a bank at an interest rate $r$.

As we show formally later, $k$ is an index of the riskiness of an entrepreneur, that is, an entrepreneur with higher $k$, ceteris paribus, chooses higher risk $s$. This is because of lower benefits in the case of project success $(s-k)$ he obtains. ${ }^{3}$ An alternative interpretation of project heterogeneity $k$ is that all projects are initially equal, but that banks can (partially) influence project risk, for example through collateral and covenants, or by monitoring.

There is a single bank which has the capacity to process one loan application (for example, for evaluating the entrepreneur's business plan). Without processing the loan application, repayment on the loan would be zero. The bank can thus only finance one entrepreneur. At an intermediate stage, there is potential entry by another bank who can make a competing loan offer for the entrepreneur. ${ }^{4}$ If the entrepreneur switches banks at this stage, he incurs costs $c>0$. They may, for example, represent the costs of negotiating a new loan contract or costs that arise because the information gained in the lending process cannot be completely transferred. These costs are an (inverse) measure of competition.

The timing of the model can be summarized as follows. At date 0 , the bank chooses an entrepreneur $k$ and processes his loan application. The bank subsequently makes a loan offer $r$ to the entrepreneur. Afterwards, the potential entrant (seeing the offer of the bank) can make a competing offer $\widetilde{r}$ (this can be interpreted as entrepreneurs 'shopping around' with their first loan offer). The entrepreneur then decides which offer to take and chooses risk $s$. At the last stage of date 0 , the winning

\footnotetext{
${ }^{3}$ Note that the expected return on a project is declining in $k$ (for a given $s$ ). Thus, our setup incorporates a natural bias against selecting higher risk entrepreneurs when competition increases.

${ }^{4}$ Note that the bank will not find it optimal to make an offer to other entrepreneurs at this stage because repayment would then always be zero. One can also allow this bank (similarly to the first bank) to process a loan application in the initial stage and then let banks compete for each other's entrepreneurs in the intermediate stage, without changing the results.
} 
bank raises one unit of deposits at rate $r^{D} .^{5}$ At date 1 , the state of nature realizes. When the project fails, the entrepreneur, and as a result also the bank, default. When the project succeeds, returns are consumed by the respective agents.

\subsection{Solution}

We solve the model backwards. The last decision is the entrepreneur's risk choice. Given loan rate $r$ and his type $k$, he chooses $s$ to maximize the expected pay-off from the project net of the interest rate payment

$$
(s-k-r) p(s) .
$$

Note that potential switching costs $c$ are sunk at the time and do not affect the optimal $s$. The corresponding first order condition is

$$
p+(s-k-r) p_{s}=0 .
$$

We write $s=s(r, k)$ to indicate the dependence of the entrepreneur's choice of $s$ on $r$ and $k$. From $p_{s}<0$ and $p_{s, s}<0$ it follows that $\frac{d s(r, k)}{d r}>0$ and $\frac{d s(r, k)}{d k}>0$, that is risk increases both in $r$ and $k .^{6}$ The reason for this is, as already discussed, that an increase in either $k$ or the loan rate $r$ reduces an entrepreneur's benefits from project success.

In the preceding stage, the entrepreneur chooses whether to switch to the entrant. Given switching costs $c$ he stays at his bank if

$$
(s(r)-k-r) p(s(r)) \geq(s(\widetilde{r})-k-\widetilde{r}) p(s(\widetilde{r}))-c
$$

i.e., if his pay-off from staying $((s(r)-k-r) p(s(r)))$ is not below the pay-off from accepting the entrant's offer and incurring the switching costs $((s(\widetilde{r})-k-\widetilde{r})$ $p(s(\widetilde{r}))-c)$.

In the second stage, loan rates are set. The lowest interest rate the entrant can set without making a loss is the deposit rate, that is, setting $\widetilde{r}=r^{D}$. We denote with $s^{D}=s\left(r^{D}\right)$ an entrepreneur's risk choice when the loan rate is $r^{D}$, and with $u^{D}$ his resulting pay-off (gross of any switching costs). $s^{D}$ is implicitly defined by Eq. 2

$$
p\left(s^{D}\right)+\left(s^{D}-k-r^{D}\right) p_{s}\left(s^{D}\right)=0 .
$$

Using Eq. 1, $u^{D}$ is then given by

$$
u^{D}=\left(s^{D}-k-r^{D}\right) p\left(s^{D}\right) .
$$

\footnotetext{
${ }^{5}$ The reason for making banks raising deposits at this stage is that at the beginning of the period it is not clear (off-equilibrium) which bank will finance the entrepreneur and hence will need to raise funds.

${ }^{6} \mathrm{We}$ have assumed that project output falls linear in $k$ in order to obtain analytical solutions. However, what is important for the results is that banks can increase their risk by switching between entrepreneurs, which is guaranteed by $\frac{d s(r, k)}{d k}>0$ and only requires that project output depends negatively on $k$. Only in the case where output does not depend on $k$ at all the bank cannot control its risk. As we discuss at the beginning of Section 2.3, then the BdN result obtains.
} 
Thus, the entrant can offer the entrepreneur at most a (net) pay-off of up to $u^{D}-c$. Therefore, the maximum interest rate $r$ the (incumbent) bank can set without losing the entrepreneur to the entrant fulfills

$$
(s-k-r) p(s)=u^{D}-c
$$

We assume that this equation is binding, that is the bank does not find it optimal to set a lower interest rate (otherwise, competition from the entrant has no effect). ${ }^{7}$

The entrepreneur's participation constraint is given by

$$
(s(r)-k-r) p(s(r)) \geq 0 .
$$

We assume that the participation constraint is not binding (relative to the interest rate constraint coming from competition from the entrant). From Eqs. 6 and 7 this condition writes $u^{D}-c \geq 0$. Note that when projects have a positive NPV (if financed at the competitive rate, $r_{D}$ ) we have $u^{D}>0$. The participation constraint then never binds when competition is sufficiently intense, that is when $c$ is small. ${ }^{8}$

Finally, in the first stage the bank selects the type of entrepreneur it wants to finance. Specifically, it chooses $k$ to maximize its expected returns

$$
\pi=\left(r-r^{D}\right) p(s)
$$

subject to $s$ and $r$ fulfilling the entrepreneur's risk choice Eq. $2^{9}$ and the limit price Eq. 6. Note that although $k$ has no direct influence on profits, it has an indirect one through the interest rate $r$ and the risk choice $s$. In the case of $s$ it can be seen from Eq. 2 that there are even two channels through which $k$ affects $s$ : a direct one and an indirect one through the impact of $k$ on $r$.

\subsection{Competition and bank risk-taking}

We first use our model to demonstrate the mechanism of BdN. Their results obtain when the bank cannot choose between different types of entrepreneurs, that is, when $k$ is fixed. From the interest rate equation (6) we have that a reduction in switching costs $c$ (higher competition) forces the bank to charge a lower lending rate $r$. This is because otherwise the entrepreneur would find it optimal to switch to the entrant. The lower lending rate in turn increases the entrepreneur's gains in the case of project success and the entrepreneur will hence reduce its level of risk (since $\frac{d s(r, k)}{d r}>0$ ). Banks thus end up safer.

We next analyze the impact of competition for when banks can choose between different entrepreneurs. For this it is useful to restate the bank's optimization problem. Since a bank's choice of $k$ maps into a risk level $s$ (and an interest rate $r$ ), we can also consider the bank's problem as one of choosing $s$ in order to maximize

\footnotetext{
${ }^{7}$ It can be shown that there may in principal be also an interior solution for $r$ (the reason is that a higher interest rate also causes a higher risk choice $s$ and hence may reduce the bank's pay-off). However, the equation always becomes binding when $c$ is sufficiently small because the maximum interest rate then becomes close to $r^{D}$.

${ }^{8}$ In the case the participation constraint binds in the bank's problem, competition will be ineffective.

${ }^{9}$ Note that the bank has to take into account the entrepreneur's FOC as an optimization constraint because the latter determines the entrepreneur's risk choice $s$ in the last stage.
} 
$\pi$. The entrepreneur who needs to be selected to induce a certain $s$, and the interest rate that results from this choice, are implicitly given by Eqs. 2 and 6 . We write $k(s)$ and $r(s)$ in the following to indicate the $k$ and $r$ that correspond to a risk choice $s$. Thus, the bank maximizes $\pi$ over $s$ subject to $k(s)$ and $r(s)$.

Consider now the impact of a small change in (induced) risk on bank's equity, i.e., the bank's marginal gains from risk-taking. From Eq. 8 we have

$$
\pi^{\prime}(s)=r^{\prime}(s) p+\left(r-r^{D}\right) p_{s} .
$$

Thus, there are two offsetting effects of higher bank risk. First, it reduces the likelihood of project success $\left(p_{s}<0\right)$ in which case an amount of $r-r_{D}$ is lost to the bank (last term in Eq. 9). Second, a higher risk-choice is associated with a higher lending rate $\left(r^{\prime}(s)>0\right)$ as previously discussed, from which the bank benefits in the case of success (first term on the right-hand side of Eq. 9).

We show in the following that a reduction in $c$ (that is, an increase in competition) raises risk-taking $s$. For this we prove that the bank's marginal risk-taking gains $\pi^{\prime}(s)$ at a given $s=\bar{s}$ increase when $c$ falls. This amounts to showing that if the bank following a reduction in $c$ (hypothetically) adjusts $k$ such that its previous risk level $\bar{s}$ is restored, its risk-taking gains are still higher than before the reduction in $c$. From this it follows that a bank implements an $s$ that is higher than the one that was optimal before the reduction in $c$.

Formally, we have to show that $\frac{d \pi^{\prime}(\bar{s})}{d c}<0$. From Eq. 9 we get

$$
\frac{d \pi^{\prime}(\bar{s})}{d c}=\frac{d r^{\prime}(\bar{s})}{d c} p(\bar{s})+\frac{d r(\bar{s})}{d c} p_{s}(\bar{s}) .
$$

since $\frac{d(p(\bar{s}))}{d c}=0$ and $\frac{d\left(p_{s}(\bar{s})\right)}{d c}=0$.

Lemma 1 We have $\frac{d r^{\prime}(\bar{s})}{d c}=0$ and $\frac{d r(\bar{s})}{d c}=\frac{1}{p\left(s^{D}\right)}>0$.

Proof

1. $\frac{d r^{\prime}(\bar{s})}{d c}=0$ : Rearranging the entrepreneur's first order condition (Eq. 2) for $r$ gives

$$
r=s-k+\frac{p}{p_{s}}
$$

Taking the total derivative with respect to $s$ yields

$$
r^{\prime}(s)=1-k^{\prime}(s)+\frac{p_{s}^{2}-p p_{s, s}}{p_{s}^{2}} .
$$

The total derivative of Eq. 12 with respect to $c$ (holding $s$ constant at $\bar{s}$, that is, $k$ implicitly changes) is

$$
\frac{d r^{\prime}(\bar{s})}{d c}=-\frac{d k^{\prime}(\bar{s})}{d c} .
$$

Combining the entrepreneur's first order condition (2) and the interest rate determination Eq. 6 to eliminate $s-k-r$ and solving for $u^{D}$ gives

$$
u^{D}=-\frac{p^{2}}{p_{s}}+c .
$$


Totally differentiating Eq. 14 with respect to $s$ gives

$$
u_{k}^{D} k^{\prime}(s)=\frac{-2 p p_{s}^{2}+p^{2} p_{s, s}}{p_{s}^{2}} .
$$

Since $u_{k}^{D}=-p\left(s^{D}\right)$ (from Eq. 5) we get for $k^{\prime}(s)$ that

$$
k^{\prime}(s)=\frac{-2 p p_{s}^{2}+p^{2} p_{s, s}}{-p\left(s^{D}\right) p_{s}^{2}} .
$$

Note that $k^{\prime}(s)>0$ ( since $\left.p_{s, s}<0\right)$, confirming that when the bank wants to induce more risk, it has to pick an entrepreneur with higher $k$. It follows from Eq. 16 that $\frac{d k^{\prime}(\bar{s})}{d c}=0$ and hence from Eq. 13 that $\frac{d r^{\prime}(\bar{s})}{d c}=0$.

2. $\frac{d r(\bar{s})}{d c}=\frac{1}{p\left(s^{D}\right)}$ : Taking the total derivative of Eq. 11 with respect to $c$ (holding $s$ constant) gives

$$
\frac{d r(\bar{s})}{d c}=-\frac{d k(\bar{s})}{d c}
$$

Totally differentiating Eq. 14 with respect to $c$ (again, holding $s$ constant) yields

$$
u_{k}^{D} \frac{d k(\bar{s})}{d c}=1 .
$$

Solving for $\frac{d k(\bar{s})}{d c}$, inserting into Eq. 17 and using $u_{k}^{D}=-p\left(s^{D}\right)$ we obtain $\frac{d r(\bar{s})}{d c}=$ $\frac{1}{p\left(s^{D}\right)}$.

Hence we have with Eq. 10 that $\frac{d \pi^{\prime}(\bar{s})}{d c}<0$, that is risk-taking increases when competition intensifies.

The intuition behind this result is as follows. From Eq. 9 we know that a bank's risk-taking choice trades off the effect of higher lending rates in the case of success $\left(r^{\prime}(s) p>0\right)$ with a lower likelihood of obtaining profits in the good state $\left(\left(r-r^{D}\right) p_{s}<0\right)$. In order to analyze the impact of competition on the bank's risk taking, we thus have to study how it may modify these two effects. Note first that an entrepreneur's probability of success and the sensitivity of this probability with respect to risk is not directly affected by the level of competition $\left(\frac{\partial p(\bar{s})}{\partial c}=0\right.$ and $\left.\frac{\partial p_{s}(\bar{s})}{\partial c}=0\right)$. Since the deposit rate $r^{D}$ is exogenously given, a change in competition can hence only affect risk-taking incentives in two ways: by changing the trade-off between lending rates and induced risk $\left(r^{\prime}(s)\right)$ and/or by changing the profit the bank obtains in case of project success $\left(r-r^{D}\right)$ through a change in the lending rate $r$.

Competition unambiguously lowers lending rates by increasing the threat that the entrant can lure away an entrepreneur. This implies that $r$ for a given type $s$ has to be lowered. We thus have that the profit a bank obtains in case of project success from a given entrepreneur, $r-r^{D}$, falls. Furthermore, even though competition reduces lending rates, it does not change the sensitivity of lending rates to entrepreneurial risk types. This is because all entrepreneurs enjoy lower switching costs and hence all equally benefit from lower lending rates $\left(r^{\prime}(s)\right.$ is thus unchanged). Summing up, while lending market competition thus reduces the costs of risk-taking by lowering a bank's profit in the case of success, it does not affect the benefits from risk-taking. As a result, the bank ends up taking more risk. 
Before concluding, let us employ our model to analyze the impact of competition in the deposit market, that is the traditional channel. Higher competition in the deposit market presumably increases deposit rates $r^{D}$. Equation 9 shows that this increases a bank's risk-taking incentives at a given $\bar{s}$ (we have $\frac{d \pi^{\prime}(\bar{s})}{d r^{D}}=-p_{s}>0$ ). Hence, the bank has an incentive to react to the increase in the deposit rates by switching to an entrepreneur with higher risk. The intuition for this result is the standard one: higher deposit rates reduce the gains a bank obtains in the case of project success and hence make the bank less concerned about the risk of failure.

\section{Conclusions}

Understanding the relationship between competition and banking stability is of paramount importance for designing banking regulation and may ultimately help to mitigate the risk of financial crises. The traditional view has held that competition in the banking sector is detrimental for stability since it tends to increase deposit rates and thus erodes the franchise value of banks. Recent literature has challenged this view and has emphasized that there is a counteracting channel, which operates through the loan market. The argument is that competition among banks tends to reduce loan rates, which makes borrowers safer precisely for the same reason that banks become riskier when deposit rates rise.

In this paper we have shown that when banks have control over their risk-taking, the stability impact of lending market competition may be reversed. This is because banks have an optimal amount of risk they want to hold and thus want to offset the impact of safer borrowers on their balance sheet by taking on more risk. Since competition in the loan market at the same time erodes banks' franchise values, they even want to overcompensate the impact of safer borrowers because their risk-taking incentives increase.

Banks arguably have plenty of opportunities to modify their risk-taking. They may direct lending to riskier projects (as in our model) but may also raise risk through various other channels, such as by weakening lending standards, reducing monitoring and screening efforts or lowering loan restrictions. There are also many ways for banks to adjust their risk beyond their loan portfolios. For example, they can invest more in risky (non-loan) assets or increase leverage. Thus, under quite plausible scenarios the lending channel may reinforce the adverse impact of deposit market competition on stability, rather than countering it.

Open Access This article is distributed under the terms of the Creative Commons Attribution Noncommercial License which permits any noncommercial use, distribution, and reproduction in any medium, provided the original author(s) and source are credited.

\section{References}

Allen F, Gale D (2000) Comparing financial systems. MIT, Cambridge

Boot A, Thakor A (2000) Can relationship banking survive? J Finance 55:679-713

Boyd J, De Nicoló G (2005) The theory of bank risk taking and competition revisited. J Finance 60:1329-1343

Boyd JH, De Nicoló G, Jalal AM (2006) Bank risk-taking and competition revisited: new theory and new evidence. IMF working paper no 06/297 
De Nicoló G, Loukoianova E (2007) Bank ownership, market structure and risk. IMF working paper no $07 / 215$

Dell'Ariccia G, Marquez R (2004) Information and bank credit allocation. J Financ Econ 72:185-214

Dell'Ariccia G, Marquez R (2006) Lending booms and lending standards. J Finance 61:2511-2546

Hakenes H, Schnabel I (2007) Bank competition and capital regulation. Mimeo, Max Planck Institute Bonn

Hauswald R, Marquez R (2006) Competition and strategic information acquisition in credit markets. Rev Financ Stud 19:967-1000

Hellman T, Murdock K, Stiglitz J (2000) Liberalization, moral hazard in banking, and prudential regulation: are capital requirements enough? Am Econ Rev 90:147-165

Keeley M (1990) Deposit insurance, risk and market power in banking. Am Econ Rev 80:1183-1200

Martínez D, Repullo R (2006) Does competition reduce the risk of bank failure? Mimeo, CEMFI Madrid

Repullo R (2004) Capital requirements, market power, and risk-taking in banking. J Financ Intermed $13: 156-182$ 